\title{
MIGUEL SERVET Y LOS ALUMBRADOS: LIBERTAD RELIGIOSA E IMPOTENCIA POLÍTICA
}

\author{
POR \\ LAURA ADRIÁN LARA ${ }^{1}$ \\ Universidad Complutense de Madrid
}

\section{RESUMEN}

En la península ibérica destacan dos experiencias en las que la reforma religiosa no va emparejada con un proyecto de reforma política ni con la institucionalización de una iglesia visible. Se trata del movimiento de los alumbrados (1525-1559) y de la obra de Miguel Servet (1511-1553). La persecución y condena que padecen por parte de la Inquisición española y el Consejo de Ginebra, respectivamente, pone de relieve la inquietud que generó su manera de entender el cristianismo y el contraste entre su impotencia y la espiritualidad armada de sus oponentes.

PALABRAS CLAVE: alumbrados; dexamiento; Miguel Servet; Martín Lutero; Juan Calvino.

\section{MIGUEL SERVET AND THE ALUMBRADOS: RELIGIOUS FREEDOM AND POLITICAL POWERLESSNESS}

\section{ABSTRACT}

In the Iberian Peninsula two cases can be found of religious reform that were not seeking to promote political reform, nor to establish a visible church: the Alumbrados (1525-1559) and the work of Miguel Servet (1511-1553). The persecution and condemnation of the Alumbrados by the Spanish Inquisition and of Servet by the Council of Geneva highlight the deep concerns their ideas raised and the contrast between their powerlessness and the armed spirituality of their opponents.

KEY WORDS: Alumbrados; Dexamiento; Miguel Servet; Martin Luther; John Calvin.

Cómo CITAR ESTE ARTículo / CITATION: Adrián Lara, L. 2018. «Miguel Servet y los alumbrados: libertad religiosa e impotencia política». Hispania Sacra 70, 141: 19-27. https://doi.org/10.3989/hs.2018.002

\author{
Recibido/Received 09-05-2017 \\ Aceptado/Accepted 09-06-2017
}

Es muy fácil mortificar al cuerpo por medio del espíritu, pero no al espíritu por medio del cuerpo. ${ }^{2}$

El 23 de septiembre de 1525 se publicó el Edicto de los alumbrados de Toledo. ${ }^{3}$ En él se condenaban 48 proposiciones atribuidas a los primeros alumbrados cuya actividad se había localizado principalmente en Guadalajara, Pastrana, Escalona y Cifuentes. La persona que había promovido este movimiento religioso era Isabel de la Cruz, una beata franciscana que, después de abandonar la casa familiar, vivía en la Parroquia de Santo Tomé de Guadalajara. ${ }^{4}$ Su actividad

\footnotetext{
1 ladrianl@ucm.es / ORCID iD: http://orcid.org/0000-00028178-4040

2 Molinos 1974: 82

3 El Edicto está reproducido en Márquez 1980: 229-238.

4 Longhurst 1957: 279-381.
}

como promotora y maestra de esta nueva espiritualidad habría comenzado hacia 1512. Después de las primeras denuncias recibidas por la Inquisición entre mayo y junio de $1519^{5}$, y tras una indagación más profunda hecha por Andrés de Écija, el provincial de la Orden de los Franciscanos, fue expulsada de la orden terciaria. Esto ocurrió a finales de 1523 o comienzos de 1524. Poco después, el 26 de febrero de 1524, fue arrestada por la Inquisición y comenzó un largo proceso que corrió paralelo al de uno de sus principales seguidores, Pedro Ruiz de Alcaraz. ${ }^{6}$ El proceso culminaría en 1529 con la condena de ambos a cárcel perpetua. ${ }^{7}$

5 Procedían de Mari Nuñez, una antigua discípula de Isabel de la Cruz que se habría convertido en su enemiga. Ibídem: 280-283.

6 Ibídem: 284.

7 Ibídem: 300 . Se sabe que el 21 de febrero de 1539 a Pedro Ruiz de Alcaraz le fue conmutada la pena de prisión perpetua por la obligación 
Entre los seguidores de Isabel de la Cruz se encontraban laicos y religiosos. Ruiz de Alcaraz pertenecía al primer grupo. Después de trabajar como contable del marqués de Priego entró al servicio de Don Diego López de Pacheco, segundo marqués de Villena, quien le contrató como «predicador laico». ${ }^{8}$ En la protección de los alumbrados fue relevante el papel de la nobleza castellana. Concretamente destaca el papel de los Mendoza de Guadalajara. ${ }^{9}$ Otros nombres destacados en esta primera expresión del alumbradismo son el de Gaspar de Bedoya y María de Cazalla, hermana del obispo Juan de Cazalla, igualmente procesados por la Inquisición. ${ }^{10}$

Después del grupo inicial de Toledo, surgieron otros grupos de alumbrados en Llerena (Extremadura) y en Andalucía. También se ha estudiado la expansión del fenómeno en Hispanoamérica. ${ }^{11}$ En este trabajo nos fijamos en el primer grupo, los alumbrados de Toledo, cuyo contenido teológico parece estar más delimitado.

La experiencia de los alumbrados tiene un origen anterior a la entrada del luteranismo. Como señala Laura Canabal Rodríguez, cuando la Inquisición hizo frente a los alumbrados en 1525 estaba afrontando el primero de los importantes retos que aguardaban al reinado de Carlos $\mathrm{V}$ para mantener la ortodoxia católica. Después tendría que hacer frente a la amenaza que supondrían el erasmismo y el luteranismo. ${ }^{12}$

Miguel Servet (1511-1553) vivió muy de cerca ese ambiente pre-reformista marcado por las innovaciones aportadas por el Cardenal Cisneros y que se gestaba en un entorno marcado por la presencia de conversos de origen musulmán y judío. ${ }^{13}$ No olvidemos que la familia de Servet era de origen judeoconverso igual que la de la mayoría de los primeros alumbrados. ${ }^{14}$ En 1525, cuando contaba catorce o quince años, su padre Antón le puso al servicio de fray Juan de Quintana (f. 1534), al que acompañaría como su paje y secretario. ${ }^{15}$ Quintana fue el autor del Edicto de 1525 contra los alumbrados de Toledo y es posible que Servet tomara parte en la transcripción de algunos documentos relacionados con ellos. ${ }^{16}$ Junto a él, Servet participaría después en un viaje con toda la

de permanecer en Toledo y cumplir ciertas penitencias. Es posible que a Isabel de Alcaraz le ocurriera lo mismo. Ibídem: 303. Serrano y Sanz 1903: 21. La Sentencia condenatoria contra Ruiz de Alcaraz, fechada el 22 de julio de 1529, puede leerse en Ibídem: 22-31. La transcripción del proceso completo de Ruiz de Alcaraz, cuyo manuscrito está en el Archivo Histórico Nacional, permanece inédita. Respecto del caso de Isabel de la Cruz, se ha publicado recientemente un documento relacionado con la venta de los bienes que le confiscó la Inquisición a propósito del proceso al que fue sometida. Véase Canabal Rodríguez 2001: 309-332.

8 Serrano y Sanz 1903: 8.

9 Márquez 1980: 61.

10 El proceso de María de Cazalla está publicado en Ortega 1978. El Sumario del Proceso de Gaspar de Bedoya está recogido en Márquez 1980: 281-293.

11 Véase Huerga 1978. García Gutiérrez 1999.

12 Canabal Rodríguez 2001: 310.

13 Sobre este contexto véase Hamilton 1992: 1-23.

14 La familia materna de Servet estaba emparentada con los Zaporta, familia de notables mercaderes de origen judeoconverso. Alcalá 2003-2007: I, XXVIII. Sobre los alumbrados castellanos, señala Márquez: "los denunciados son todos de familia de conversos: los denunciantes son cristianos viejos». Márquez 1980: 62.

15 Ibídem: 45-50.

16 Servet podría haber sido el encargado de transcribir los Sumarios de los procesos de Pedro Ruiz de Alcaraz. Márquez 1989: 181-190. corte de Carlos V (1500-1558) a Italia que culminaría con su coronación en Bolonia en febrero de 1528. Los fastos y el estilo de practicar la religiosidad que vio en este viaje le resultó muy decepcionante. ${ }^{17}$ No es extraño que buscara maneras alternativas de comprender su fe. Con este criterio cabe suponer que viajó a Basilea y Estrasburgo. En Basilea fue discípulo y se alojó en casa de Johannes Oecolampadius (Ecolampadio, 1482-1531), quien había sido colaborador de Erasmo de Rotterdam (1466-1536) y era entonces el líder religioso de la ciudad. La relación se tensó pronto, y a partir de la publicación de sus obras Siete libros sobre los errores de la Trinidad (1531) y Dos libros de diálogos sobre la Trinidad (1532), el entorno se volvió cerrado y hostil para él. Los cruces de cartas con él y entre los líderes religiosos del área germánica muestran un rechazo frontal a sus planteamientos. ${ }^{18}$ Igualmente trató de comunicarse con Calvino (Jean Calvin, 1509-1564), con quien mantuvo una relación muy tensa. ${ }^{19}$

Por sus planteamientos sobre la Trinidad, Servet era un personaje non grato tanto para los católicos como para las Iglesias luteranas y calvinistas, que en este punto se mostraban de acuerdo. Valgan de ejemplo las palabras del nuncio del papa en Alemania Girolamo Aleandro (1480-1542):

Sería deber de estos herejes de Alemania, luteranos o zwinglianos, dondequiera que se halle, que se decidieran a castigarlo, si es que son tan buenos cristianos y evangélicos [...] pues que él no es menos contrario a la fe que ellos profesan que a los católicos, y en algunos lugares de esa obra nominalmente contradice a Lutero, a pesar de que está en tierra de luteranos. ${ }^{20}$

El 27 de octubre de 1553 Servet murió en la hoguera, después de haber sido procesado y condenado por el Consejo de la ciudad de Ginebra. ${ }^{21}$

\section{LA DIVINIZACIÓN DEL INDIVIDUO}

Desde la formulación de Martín Lutero (Martin Luther, 1483-1546) del principio del sacerdocio de todos los creyentes, el papel mediador de la Iglesia de Roma, o de cualquier otra institución humana que ocupe su lugar, queda en entredicho. Cada individuo, como cristiano, está vinculado con Dios de manera directa y en igualdad de condiciones, sin que exista una jerarquía entre los hombres que establezca diversos grados de cercanía o cierta preeminencia de algu-

17 «Con mis propios ojos vi yo mismo cómo los príncipes le llevaban con pompa sobre sus hombros, mientras fulminaba cruces con la mano, y cómo le adoraba todo el pueblo de rodillas a lo largo de las calles... iOh, Bestia, la más vil de las bestias, la más desvergonzada de las rameras!», escribiría años más tarde. Alcalá 2003-2007: VI, 1093 (IV, II, II).

18 Véase ibídem: I, 57-63.

19 Sobre la dureza de los ataques mutuos ha escrito Tausiet 2010: 181-211.

20 «Carta del nuncio en Alemania, Girolamo Aleandro, en la que delata a Servet (17 de abril de 1532)», en Alcalá 2003-2007: I, 32. Aleandro promovió la condena de la obra de Servet por la Santa Sede y dio aviso a las autoridades españolas «para que se hagan proclamas e incendios del libro y de la estatua del hereje al modo de España». Ídem. Sobre las relaciones de Servet con el mundo católico y el reformado, véase el volumen IV de Alcalá 2003-2007.

21 La sentencia lo condena por la publicación de sus ideas sobre la Trinidad y por no aprobar el bautismo de los niños. Puede leerse en Alcalá 2003-2007: I, 247-250. 
nos sobre otros; por ello, el orden del sacerdocio no puede instituirse como un sacramento que distinga a unos hombres de otros: es meramente un cargo que desempeñan ciertas personas en beneficio de la comunidad, pero que en nada altera su estado. ${ }^{22}$ Además de establecer esta igualdad básica, con resonancias y consecuencias políticas tan profundas, se subraya que el vínculo entre los cristianos y Dios no requiere ninguna mediación humana y es perjudicial que la haya.

Con gran entusiasmo reconocerá Calvino el cambio que ha supuesto la encarnación de Dios en la figura de Cristo. Mientras los judíos debían conformarse con relacionarse con un Dios escondido e inefable, los cristianos han gozado de su presencia en la tierra, han podido ver y tocar a su Dios que ha adquirido naturaleza humana. El Nuevo Testamento inaugura una nueva etapa que permite superar la anterior, en la que apremiaban la fragilidad y la incertidumbre y el peligro constante de caer en la idolatría ante la desesperanza y el miedo al abandono ${ }^{23}$ :

Mais quand finalement la sagesse de Dieu a esté manifestée en chair, elle nous a déclairé à bouche ouverte tout ce qui peut entrer de Dieu en l'humain esprit, et tout ce qui s'en peut penser. Puis, dy-ie, que nous avons lesus Christ le Soleil de iustice luisant sur nous, il nous donne parfaite clairté de la vérité de son Père, comme en plein midy, au lieu qu'elle n'estoit pas auparavant du tout descouverte, mais aucunement obscure. ${ }^{24}$

En esta tesitura, el pensamiento cristiano reformado refuerza la fortaleza y la autonomía del individuo que se reconoce capacitado para sostener por sí mismo ese vínculo con Dios, y lo hará a través del acceso directo a un objeto que aparece cargado de poder: la Biblia. Una de las murallas que derribó Lutero fue la del monopolio que ostentaba la Iglesia de Roma para interpretar las Escrituras..$^{25}$ Esto significó una liberación de gran trascendencia, revolucionaria; aunque en la práctica no significara que, inmediatamente, cualquiera pudiera leer la Biblia e interpretarla según su criterio, ni que fuera un ejercicio exento de angustia. ${ }^{26}$

En esta cuestión, es relevante observar que ese vínculo con Dios a través de Cristo se asume como una jubilosa divinización del individuo. ${ }^{27}$ Este es un punto clave que separa radicalmente al judaísmo del cristianismo: mientras Yahveh es comprendido en un más allá separado e inaccesible al mundo humano, con la llegada del Mesías el Dios cristiano rompe de manera irreversible esa distancia metafísica y se introduce en el tiempo de los hombres. Esta diferencia teológica tiene trascendencia teórico política pues supone una relación esencialmente distinta, en una y otra tradición, con la noción de omnipotencia. ${ }^{28}$

22 Lutero 1986: 9, 11.

23 Calvino habla de ello en relación con los ídolos como el becerro de oro. Calvin 1957: I, 129-130 (I, XI, 8).

24 Ibídem: IV, 158 (IV, VIII, 7).

25 Lutero 1986: 8, 11-12.

26 Véase por ejemplo Simpson 2007.

27 Así lo expresa Servet: «La palabra, al descender del cielo a la tierra, arrastra a su vez la tierra hacia el cielo, haciéndonos a todos celestiales». Alcalá 2003-2007: V, 127 (I, II, IX). Véase Calvin 1957: II, 191 (II, IX, 2).

28 Para un desarrollo de esta idea, planteada por Eric Voegelin (1901-1985), véase Roiz 2003: 69 y ss.
Varios rasgos presentes en el pensamiento de Servet y en la doctrina de los alumbrados nos llevan a considerar que, cada uno a su manera, en muchos momentos se separan de esa visión cristiana predominante en la que se inflama la voluntad del individuo como un mecanismo básico de gobierno y vía para la emancipación individual y colectiva, y que alcanza una expresión emblemática en la mentalidad calvinista. ${ }^{29}$ Este énfasis en la voluntad se proyecta políticamente en la creación de poderes ejecutivos fuertes. Como se observa en los juicios de Toledo y de Ginebra, los alumbrados y Servet estaban ante instituciones bien organizadas y dispuestas a actuar como el brazo armado de sus dogmas respectivos. Un aspecto este -el de la organización institucional y la disposición militante- del que ambas expresiones religiosas carecieron.

El trágico destino de sus protagonistas nos muestra, como la imagen del Quijote vencido en la playa de Barcelona, su impotencia política ante dos iglesias muy poderosas.

\section{LA PERSONA DE CRISTO Y LA IDOLATRÍA DE LA TRINIDAD}

En el pensamiento de Servet, hay un punto de fricción muy profundo con la ortodoxia cristiana y que le costará la condena a muerte en Ginebra: la noción de la Trinidad. Servet la considera una idolatría, como la consideran los judíos a los que, en este aspecto, se siente más cercano ${ }^{30}$ :

Son tantos los textos en que se apoyan los hebreos que se asombran con razón ante el Dios tripartito inventado por los nuestros. Estiman que es cismático nuestro Testamento, al ver cómo nos alejamos de la unidad y simplicidad de su Dios, y porque ni uno solo de sus antepasados pudo pensar jamás tal cosa. ${ }^{31}$

Para poder revelar los errores cometidos por quienes amparan esta noción, se propone replantear la comprensión del término persona. Con ello, nos ofrece un entendimiento más sutil de la cuestión, que toma distancias de una grosera humanización de Dios.

Considera que la noción de "persona», tal y como la entienden los trinitarios, conlleva entender a Dios de una forma inadecuada, pues despedaza su unidad y con ello hace caer a los cristianos en un politeísmo inaceptable. "Persona», apunta Servet, no ha de comprenderse como una entidad invisible, incorpórea y eterna. De ser así, argumenta, desde la eternidad habrían existido tres entidades simultáneas, el Padre, el Hijo y el Espíritu Santo; tres entidades como tres fantasmas en los que creer convirtiendo a los cristianos en triteístas, o lo que es lo mismo, en ateos:

29 Muestra de ello, a nuestro juicio, es la manera de comprender y poner en práctica el activismo político. Véase el magistral estudio de Walzer 2008.

30 Alcalá advierte, no obstante, que el antitrinitarismo de Servet no tiene por qué indicar ninguna posible conexión judía: "La posición servetiana acerca de la Trinidad nada tiene que ver, en principio, con postularse casta judía, pues antitrinitarios y unitarios de todo tipo, pero no judíos, los ha habido y los hay en abundancia. El bien matizado antitrinitarismo servetiano radica en una lectura radical de los textos bíblicos y de los escritores cristianos anteriores al Concilio de Nicea del año 325». Alcalá 2003-2007: I, XXXV.

31 Alcalá 2003-2007: V, 65 (I, I). «[E]ntre los judíos jamás se había oído nada de la Trinidad o de un hijo invisible». Ibídem: V, 16 (I, I). "[L]os judíos[...] jamás concederían en Dios esas tres entidades». Ibídem: V, 231-232 (I, IV). 
Verdaderamente son ateos todos los trinitarios. Porque, ¿qué otra cosa es ser sin Dios que el no poder ni siquiera pensar en Dios sin que se interfieran amenazantes en nuestra mente esas tres entidades que nos confunden y nos hacen enloquecer cuando pensamos en él? ${ }^{32}[\ldots]$ Son verdaderos triteistas y verdaderos ateos, pues no admiten un solo Dios, sino un Dios tripartito y acumulado. Tienen un Dios connotativo, pero no absoluto. En realidad, tienen dioses imaginarios, delirios diabólicos. ${ }^{33}$

Aplicar al término persona un contenido metafísico supone un abuso; y al aplicar tal acepción a Dios diciendo que en él confluyen tres personas implica desmembrarlo ${ }^{34}$, como si de él pudieran distinguirse tres elementos, o fuera el conjunto de los tres, en cuyo caso incluso podría decirse que hay "una cuaternidad». ${ }^{35}$

Para restaurar la comprensión original de Cristo, Servet trata de entenderlo como lo harían los primeros conversos y nos dice que para ellos «persona» tiene el sentido de rostro:

Tanto en las Escrituras, como en otras partes, se llama siempre persona al aspecto externo de un hombre, a su rostro, a su representación, como cuando decimos de alguien que su persona es hermosa[...] Para los hebreos la cosa está clara: ellos llaman persona a lo que nosotros llamamos rostro. ${ }^{36}$

Junto a ello, retoma la comprensión clásica de persona, basada en su etimología ${ }^{37}$, que toma tal vez del humanista Lorenzo Valla (ca. 1406-1457): persona vendría de personare, "sonar a través». ${ }^{38}$ Así, esta palabra latina que sirve de origen al término en muchas lenguas europeas, "persona», se refería a la máscara que usaban los actores en las obras de teatro para cubrirse el rostro e interpretar a los distintos personajes. Con esta máscara los actores mostraban una apariencia distinta, pero podían ser reconocidos por su voz.

Podemos considerar que con esta interpretación Servet trata de proteger la identidad de Dios, cuyo conocimiento absoluto está fuera del alcance de la inteligencia humana, de una operación metonímica (en la que una parte de su ser sería tomada por el todo). Desde el planteamiento de Servet, la personalidad de Dios sería la forma en la que él se presenta ante los hombres en el escenario corpóreo de la vida, donde operan las medidas y los intervalos de tiempo de los que Dios es ajeno. ${ }^{39}$

Para los hombres hay una secuencia temporal en el conocimiento de Dios; primero solo ven a Dios a través de

\footnotetext{
32 Ibídem: V, 60 (I, I). Cursiva en el original.

33 Ibídem: V, 57-58 (I, I).

34 Ibídem: V, 186 (I, III).

35 «Pues tienes cuatro imágenes, ya que la cuarta es la imagen de la esencia, pues es imprescindible, para entender la esencia, abstraerla de alguna imagen». Ibídem: $V, 59(I, I)$.

36 Ibídem: V, 186-187 (I, III)

37 Ídem.

38 Véase Alcalá 2003-2007: V, XLV-XLVI. La interpretación de Valla
} venía a corregir la interpretación de Anicio Manlius Severino Boecio (480-524), para quien persona hacía referencia a una "sustancia individual de naturaleza inalterable». Para Valla, sin embargo, persona debía entenderse como "la cualidad por la que nos diferenciamos unos de otros en alma, cuerpo y rasgos externos». Ídem.

39 Ibídem: II-I, 304. Compárese con la explicación que ofrece Calvino de la ascensión de Jesucristo a los cielos. Calvin 1957: IV, 410-414 (IV, XVII, 27-28). la Palabra, "palabra corporal» la califica Servet..$^{40}$ Después adquieren el privilegio de verlo a través de Cristo cuando este ha nacido. Pero para Dios no hay pasado, presente y futuro ${ }^{41}$, de modo que la Palabra y Cristo existen desde toda la eternidad y su origen es simultáneo. Como dice el comienzo del evangelio de Juan, en el inicio era el logos. ${ }^{42} \mathrm{Y}$ el logos de Dios tiene la capacidad omnipotente de crear lo que dice sólo con pronunciarlo ${ }^{43}$ :

La forma de este hombre estaba desde la eternidad engendrada en Dios sin ninguna distinción real. Engendrarlo era en Dios lo mismo que pensar esa generación y simultáneamente realizarla: era constituir esa generación en tendencia a la generación misma, como proyectar una ciudad implica la tendencia a edificarla. ${ }^{44}$

Lo que Dios pronunció al decirlo, eso era el Cristo. Hablando lo pronunció, y manifestó lo que estaba en su concepto interno, creando todas las cosas por su mera pronunciación. ${ }^{45}$

De ese modo, Servet sella una identidad indivisible entre Dios, su Palabra y Cristo, que serían distintas facetas o manifestaciones de una esencia única.

Esa unidad de Dios está muy presente en las convicciones de los alumbrados. ${ }^{46} \mathrm{Al}$ igual que está presente la prevención de evitar pensar en exceso en la figura de Cristo, algo que Antonio Márquez considera peculiar de esta secta en el contexto de las diversas corrientes de la Reforma y que los hace cercanos al antitrinitarismo de Servet. ${ }^{47}$

Este elemento de la doctrina de los alumbrados se refleja en la proposición número 42 del Edicto de los alumbrados de Toledo de 1525:

Dixo uno que no quería que entre Dios y cierta persona oviesse medios, porque le avía dado por consejo el Padre de Olmillos que tuviesse en su corazón una cruz; e diziéndole la dicha persona que es menester para llegar a Dios por medio de la humanidad de lesuchristo, dixo: "mucho sabéis, no querría que supiessedes tánto». Y diziéndole más esta persona que tenía ciertas devociones de la pasión, dixo que dexasse aquellas devocioncillas y que no leyesse en la pasión, sino en los beneficios de Dios. ${ }^{48}$

40 Alcalá 2003-2007: V, 206-207 (I, III).

41 Ibídem: V, 97 (I, II, II); ibídem: II-I: 248-249.

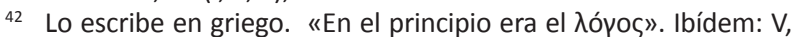
$87(\mathrm{I}, \mathrm{II}, \mathrm{I})$.

43 Ibídem: V, 94 (I, II, I).

44 Ibídem: IV, 173.

45 Ibídem: IV, 184.

46 En la Sentencia que dictó la Inquisición de Toledo contra Pedro Ruiz de Alcaraz el 22 de julio de 1529, se lee que una de las acusaciones que se le hicieron fue que consideraba que «Dios era uno y sin diuision». Serrano y Sanz 1903: 24.

47 «Si hay algo que distinga a los alumbrados dentro de las corrientes de la Reforma es esta ausencia de Cristo en sus doctrinas[...] El que siempre haya habido dudas sobre el trinitarismo de Valdés y el que nuestro otros gran heresiarca (Miguel Servet) sea uno de los padres del unitarismo moderno, son datos que no deben despreciarse tratándose de figuras procedentes de un medio profusa y profundamente semitizado». Márquez 1980: 150.

48 Ibídem: 237. En la Sentencia contra Pedro Ruiz de Alcaraz puede leerse que se le acusaba de: «que no mentaua el nombre de Ihesu Xpo. y de su sagrada passion, ni de nuestra Señora la Virgen Maria, y si alguno lo mentaua no les fazia buen rostro, y diziendole cierta persona que era bueno para seruir a Dios hazer vna cruz dentro de si mismo en su anima, en que viese de continuo a nuestro Redemptor cruçificado, el dicho Alcaraz le avia dicho que no quería el que entre Dios y la tal persona ouiese medios». Serrano y Sanz 1903: 25. 
Como se lee a continuación, los inquisidores la consideraron una proposición "herética» y "errónea» por estas razones:

Afirmar que Nuestro Señor lesuchristo crucificado no es medio para que el ánima fiel sea con Dios ayuntada, es proposición herrónea y herética, porque paresce negar el hijo de Dios aver encarnado y ser medianero entre Dios y los hombres; y la última parte desta proposición es contumeliosa contra el misterio de nuestra redempción, porque aparta a los hombres de la muy saludable meditación de la pasión de Nuestro Señor lesuchristo, y es herrónea y tiene sabor de heregía contra la común costumbre de la Sancta Yglesia. ${ }^{49}$

Este planteamiento puede interpretarse como una radicalización de la idea de no intermediación humana entre los hombres y Dios. A diferencia del planteamiento luterano de la sola scriptura y de la sola fide, para los alumbrados en el vínculo íntimo con Dios no debe mediar nada, ni siquiera la figura de Cristo o las Escrituras. Los alumbrados «no solo resuelven la Escritura en la Fe», señala Márquez, "si no que disuelven ésta en el amor de Dios». ${ }^{50}$ Ciertamente lo que recomiendan estos creyentes es dejarse en el amor de Dios, un estado que no requiere de rituales externos ni de movimientos del cuerpo, ni de un lugar o momento especial para orar. ${ }^{51}$

\section{EL LENGUAJE DE LOS PROFETAS Y LA INTERPRETACIÓN DE LAS ESCRITURAS}

Del Proceso de Isabel de la Cruz apenas se conservan algunos extractos, que están insertos en el Proceso contra Ruiz de Alcaraz. En ellos, se recogen las cinco declaraciones que Isabel de la Cruz hizo ante los inquisidores toledanos entre el 19 de septiembre de 1524 y el 26 de enero de $1525 .{ }^{52}$ En la confesión del 19 de septiembre de 1524 mostraba su arrepentimiento por varios errores, entre ellos este:

El segundo error de que se siente culpada es que carescia de umildad en quanto se entremetia en las consciencias de los otros e tanbien le venia de aqui pensamiento e lo dezia que los otros eran curiosos en escudriñar las cosas delas Sagrada escriptura e no tomarlas en umiliacion sino en escudrinacion lo qual dezia que era falta sino tomar la sacra escriptura en espíritu y en umildad y que quando se tomava por curiosidad que era muy gran falta de espíritu e por esto dezia que la letra matava. ${ }^{53}$

Según muestran los testimonios recopilados por los tribunales de la Inquisición, los alumbrados se reunían en conventículos para leer y comentar pasajes de las Escrituras. De modo que comprenderlas era importante para su fe, pero su acercamiento a ellas dista de ser intelectual y, desde luego, no se encomiendan a ellas como si fueran un «papa de papel». ${ }^{54}$ Desconfían de los estudiosos que llegan a ellas por las letras más que por el espíritu y que tratan de saber

\footnotetext{
49 Márquez 1980: 237.

50 Ibídem: 151.

51 Este último aspecto se señala en la Sentencia contra Alcaraz. Serrano y Sanz 1903: 25.

52 John E. Longhurst recoge el texto de estas confesiones. Longhurst

53 Longhurst 1957: 285
} 1957: 284-295.

54 Márquez 1980: 114. más de lo que Dios les da a conocer. Según consta en la sentencia contra Alcaraz, este:

Dezia que era soberuia querer entender las Escripturas mas de aquello que suenan, e que no avian de curar de saber las figuras de la Sagrada Escriptura, ni avian de inquirir como es esto o estotro, y que no avian de ser curiosos, sino pasar adelante ${ }^{55}$; [...]diziendo[...] que los predicadores no avian de inquirir ni estudiar lo que avian de predicar, por via de letras, sino en spiritu lo que Dios les ofresçiese; que todo quanto los predicadores pedían a Dios era propiedad, mas de dexarle hazer su voluntad, e menospreciaua a los honbres que no andauan segund spiritu, sino segund letras e dotrina, llamándolos literales; y que ansi mismo dezia que no era bien meterse los hombres religiosos, ni estaua bien con ellos. ${ }^{56}$

Entre los primeros alumbrados no había teólogos ni personas de gran erudición ${ }^{57}$, pero sí eran personas sensibles y abiertas al estudio..$^{58}$ Son figuras que surgen en los márgenes de la Iglesia oficial y de las universidades. De hecho, carecemos de cualquier escrito que exponga su doctrina. ${ }^{59}$ Lo que conocemos de ella es a través de sus propios testimonios y los de los testigos recopilados en los procesos emprendidos por la Inquisición para castigar su herejía. El caso de Servet es diferente. Es una persona culta, con formación filosófica y filológica. Su aproximación a las Escrituras se basa en un estudio profundo de las mismas, que solo puede hacerse conociendo el hebreo y el griego. Así lo advierte: "comete graves errores el que sin conocer la lengua santa se mete a tratar las Santas Escrituras». ${ }^{60}$ Contra lo que se revela es contra la interpretación escolástica, que a su juicio deforma el saber genuino que contienen. Para Servet, los cristianos que intentan entender la Biblia desde la filosofía griega, y no en sí misma, son «teosofistas» y no verdaderos teólogos. ${ }^{61}$ "Dos pestes gravísimas nos han quitado a Cristo: el fermento de Aristóteles e ignorar la lengua hebrea», señala. ${ }^{62}$ Abundando en la mala influencia de Aristóteles, explica:

Esta peste filosófica nos ha sido producida por los griegos, pues[...] son los más entregados a la filosofía y nosotros, pendientes de su boca, nos hemos hecho también filósofos ${ }^{63}[. .$.$] Es sorprendente que nosotros$ busquemos la sabiduría de Aristóteles, más que la de

55 Basándose en ello, el Edicto de 1525 consideró herética esta proposición, numerada como la 45: «Que no abian de ser curiosos en saber las figuras de la Sagrada Escriptura: e que si entendían algo, bien, e sino, que passassen adelante; e que era soverbia querer entender las Escripturas más que aquello que sonaba, si Dios no se lo daba». Ibídem: 237.

56 Serrano y Sanz 1903: 26.

57 Por ejemplo, ni Isabel de la Cruz ni Pedro Ruiz de Alcaraz sabían latín. De ahí que Isabel de la Cruz se excusase de haberse entrometido en estas cuestiones siendo «muger y sin letras». Longhurst 1957: 285. A este respecto, Ortega destaca que «la capacidad intelectual de la mujer era considerada nula por los teólogos de la época - Melchor Cano y el arzobispo Carranza, entre otros muchos». Ortega 1978: 55.

58 Véase Márquez 1980: 124-129.

59 Mari Nuñez sugiere en su acusación que Isabel de la Cruz podría estar preparando un libro que solo debía publicarse cuando ella ya no viviera, aunque no sabemos si tal acusación tenía algún fundamento. Longhurst 1957: 295.

60 Alcalá 2003-2007: V, 119 (I, II, VII).

61 Ibídem: II-I, 15 y 25.

62 Ibídem: II-I, 366. Se trata de una nota escrita al margen. Ibídem: II-I, XXIX.

63 Ibídem: II-I, 227. 
Dios, y fijemos nuestra atención en él con absoluta diligencia de manera que excusamos sus palabras. Si él estaba entre tinieblas, ¿¿cómo puede darnos luz?64

La comprensión de la Palabra de Dios requiere sutileza y espiritualidad. Él se resiste a aceptar la suplantación de esa espiritualidad por la metafísica escolástica y por ello destaca, por una parte, el sentido natural de las palabras, un sentido que entendería con ingenuidad cualquier cristiano, y, por otra, valora la capacidad evocadora del lenguaje para acercarse a comprender una realidad inasible.

Considera que la palabra de Dios no se dirige a «filósofos expertos en hipóstasis, sino al pueblo, a niños y a mujeres» ${ }^{65}$; se expresa de modo que todos ellos pudieran entenderlo. Es importante conocer y tener en cuenta los hechos históricos. ${ }^{66}$ Sus críticas a los teólogos filósofos, que él califica continuamente de sofistas, se deben a que no consiente que se invada el significado natural de las Escrituras con términos filosóficos ajenos a ellas. Se trata de palabras a las que dotan de una vida «espectral». ${ }^{67}$ Esta es una operación inaceptable porque confunde la espiritualidad divina con un mundo poblado por «entidades imaginarias y metafísicas» ${ }^{68}$ :

Las palabras de Cristo resultan, efectivamente, tan familiares que es algo completamente enloquecido violarlas con tales ilusiones ${ }^{69}[. .$.$] Yo querría que aban-$ donaran su costumbre de hablar metafísicamente, que examinaran atentamente los espíritus celestes no según la naturaleza del ser - porque eso nunca lo menciona la Escritura-, sino en la medida en que reluce en ellos el carácter de la divinidad, de manera que todo tienda a la gloria de Dios. ${ }^{70}$

Calvino también se había hecho cargo de entender que el lenguaje de las Escrituras estaba adaptado al entendimiento humano. ${ }^{71}$ Sin embargo, a nuestro juicio, un punto clave les separa. Mientras Calvino adopta como emblema el principio de no contradicción ${ }^{72}$, asumiendo que la palabra de Dios ha cristalizado en el testimonio de Cristo y no hay lugar para nuevas profecías ${ }^{73}$, Servet parece aceptar —con su manera

64 Ibídem: II-I, 299.

65 Ibídem: II-I, 258. La misma idea también en ibídem: |I-I,150 y 155.

66 Ibídem: V, 127 (I, II, VIII).

67 «Y las demás nociones sobre esas entidades indivisibles de las que hacen alarde los sofistas no son nada. Ante la mirada de Dios son una estupidez; están enloquecidos por sus propios fantasmas y espectros». Alcalá 2003-2007: II-I, 249. Véase ibídem: II-I, 154-155, 207-208, 221 y 237.

68 Ibídem: II-I, 215.

69 Ibídem: II-I, 247.

70 Ibídem: II-I, 269.

71 Calvino señala que al hablar a los hombres Dios hace como las «nodrizas» (nourrices) que tienen que adaptar el lenguaje a los niños para que estos puedan entenderle. Dios nos habla de un modo imperfecto para Dios, como si «balbuceara». Calvin 1957: I, 145 (I, XIII, 1).

72 «...auquel [Dieu] il n'y a point d'ouy et nenny; c'est-à-dire, qui ne se change ne contredit point». Ibídem: IV, 447 (IV, XVII, 50). Véase también ibídem: I, 114 (I, IX, 2) y IV, 407 (IV, XVII, 24). El principio de no contradicción queda consagrado en la Metafísica de Aristóteles. Véase Aristóteles 1982: libro IV, 3-4, 1005b, líneas 19-34; 1006a, líneas 10-12. Cf. con la idea que expone Leo Strauss: «la Biblia no enseña jamás que pueda hablarse de la Creación sin contradecirse». Strauss 1996: 104.

73 A partir de la lectura de Heb. I, 1-2, Calvino señala que el Apóstol «déclaire que cy après Dieu ne parlera point comme paravant, par les uns ou les autres, et qu'il n'adioustera point prophéties sur prophéties, ne révelations sur révelations; mais que tellement il a accomply toute perfection d'enseignement et son Fils, qu'il nous fait savoir que de escribir ${ }^{74}$ y de interpretar las Escrituras - que el lenguaje aparentemente contradictorio no es defectuoso ni confuso. Más bien nos está revelando una realidad tan rica que no cabe en las hechuras lógicas de la lengua y la razón humanas. Con ello, Servet da entrada a la capacidad letárgica de la inteligencia. ${ }^{75}$ Veamos algunas muestras de su planteamiento.

Para Servet la Palabra de Dios no es algo que se ofrezca a la inteligencia de forma directa. Requiere una elaboración por parte del lector. Esto exige unos conocimientos especiales, basados en el estudio concienzudo y el gusto por la precisión. Pero además se requiere una actitud especial. Según Servet, «hay que leer a los profetas de tal manera que viendo una cosa con los ojos, otees otra más sublime con el espíritu». ${ }^{76}$ También con otra metáfora indica que la Palabra de Dios es "como una espada de dos filos». ${ }^{77}$ Una palabra puede significar dos cosas al mismo tiempo y así ofrecernos un doble significado del texto, el literal y el verdadero:

A este propósito suele citarse el salmo 71: «Ante el sol será engendrado o será prohijado su nombre». Ante el sol, innon semo. El sentido literal se refiere a Salomón[...] Pero aquí el sentido verdadero hace referencia a la verdadera propagación de la filiación del Cristo en los suyos. $Y$ así no se trata de prioridad en el tiempo, "antes del sol», sino "ante el sol», «mientras dure el sol». Pues el término hebreo liphné puede significar ambas cosas. ${ }^{78}$

$\mathrm{O}$ admitir que en un mismo enunciado se condensen dos significados que podrían parecen incompatibles:

Date cuenta, sin embargo, de lo artificiosamente que dice Isaías, en dicho cap. 7, הרה'ולדת, hara veiolédeth, encinta y parturienta, o sea, concibiendo y pariendo; de tal modo que sus palabras pueden referirse al pasado y al futuro "como una espada de dos filos». Pues en aquel entonces ya había nacido Ezequías, como explica Isaías en el capítulo siguiente repitiendo las mismas palabras: «Me llegué, dice, a la profetisa que había concebido y parido un hijo, en cuya infancia se consumó la destrucción de Damasco y Samaria». ${ }^{79}$

Reconoce que la palabra de Dios «en ocasiones puede resultar incluso ambigua» y que "para que pueda darse un sentido más fecundo» se pueden admitir "varios sentidos verdaderos». ${ }^{80}$ En otras ocasiones, su lenguaje adquiere un tono casi poético. Por ejemplo, cuando explica cómo se produjo la fecundación de María:

cestuy-cy est le dernier et éternel tesmoignage que nous aurons de luy». Calvin 1957: IV, 158 (IV, VIII, 7).

74 Newman destaca las peculiaridades del estilo de Servet. Newman 1966: 535.

75 Sobre el concepto de letargia véase Roiz 2008.

76 Alcalá 2003-2007: V, 117 (I, II, VI).

77 Ibídem: V, 125 (I, II, VII). Servet toma la expresión de la carta a los Hebreos: «la palabra de Dios es una espada que corta por ambos filos» (Heb. 4). Ibídem: V, 117 (I, II, VI).

78 Ibídem: V, 95 (I, II, I).

79 Ibídem: V, 125 (I, II, VII). En su obra De los errores acerca de la Trinidad Servet expone una aclaración valiosa: «[Q]ue en Dios no hay diferencia de tiempos se argumenta por la propiedad o el uso habitual del lenguaje de los Profetas, pues anuncian cosas futuras como si hubieran pasado y al mismo tiempo al revés, y un tiempo, a menudo, es utilizado por otro, mostrando así no solo la consistencia del asunto, sino también que en Dios no hay tres diferencias de tiempos». Alcalá 20032007: II-I, 248-249.

80 Ibídem: V, 117 (I, II, VI). 
En la creación fueron creadas por separado la materia de la tierra y la del agua, y de la materia del agua fueron hechos el aire y el cielo entero. Se demuestra también por la generación misma del Cristo, que muestra la infinita distancia entre esos elementos, pues en el Cristo concurren los tres elementos superiores, que tomó de la sustancia de su Padre: del mismo modo que nuestro semen paterno es acuoso, lleno de espíritu aéreo o ígneo, así también en el caso del Cristo, aquella nube del oráculo de Dios, entre acuosa, aérea e ígnea, condensada en agua y que hizo sombra a María, fue el rocío de su generación natural sin que tuviera nada de térreo. ${ }^{81}$

Con este acercamiento a la Biblia, Servet se muestra respetuoso con la capacidad de los hombres para ofrecer su interpretación, al tiempo que reconoce que estas interpretaciones pueden estar equivocadas y que ningún sabio puede arrogarse la posesión de la verdad absoluta. ${ }^{82}$ En este contexto es comprensible que se acerque a distintas fuentes tanto cristianas como extra-cristianas ${ }^{83}$ en busca de la verdad.

\section{LA LUZ DE DIOS ${ }^{84}$}

Para Servet, Dios está presente en todos los objetos y los seres del mundo que él mismo ha creado. ${ }^{85}$ Dios está presente como una luz que viene desde dentro de los objetos y los seres. ${ }^{86}$ En su planteamiento se confunden un sentido intelectual de la luz de corte platónico, como fuente de inspiración de la verdad, con un sentido espiritual, en el que la luz representa la faceta creadora y amorosa de Dios hacia todos los seres y el mundo:

La luz es lo más hermoso de este mundo y del otro. Todo ser consiste en la idea misma de luz en la que resplandece. Luz y solo luz informa y transforma todos los seres celestes y terrestres, espirituales y corporales. De luz procede toda esta hermosura y ornato del mundo. El Creador infundió formas luminosas en los seres para que no permaneciesen más tiempo en aquél informe y tenebroso caos. En todo lo generable y corruptible la llegada del sol a nosotros es causa de generación; su retirada de corrupción. El rayo solar modera de tal modo la combinación de elementos que solo se vea una resplandeciente perfección de forma. Nada puede enviar por sí mismo al ojo o al espejo una forma de luz o su imagen natural si no contiene luz en sí mismo y formalmente. Si lo meditas bien, la fuerza de este razonamiento es enorme. Luz es la forma visible de todas las cosas. Luz es todo lo que aparece (Efes. 5). Luz es también lo que de diferentes maneras transforma la materia eterna y líquida en piedras resplandecientes, en luminosas margaritas y en todas las demás cosas que formalmente vemos por medio de la luz. Y luz es lo que en la regeneración transforma e informa nuestro espíritu, como luz será también lo que transformará nuestros cuerpos en la resurrección final. ${ }^{87}$

Del mismo modo que la luz tiene la capacidad para crear y transformar la naturaleza, también «en lo espiritual toda

81 Ibídem: V, 270 (I, IV).

82 Véase la Carta de Servet a Ecolampadio, en ibídem: I, 13-15.

83 Entre ellas, el Talmud y el Corán. Ibídem: V, 64-68, 86.

84 Con gran interés, María Tausiet ha destacado este aspecto del pensamiento de Servet. Tausiet 2013: 92-95.

85 Alcalá 2003-2007: V, 203-205 (I, III).

86 Ibídem: V, 205 (I, III).

87 Ibídem: V, 256-257 (I, IV). energía deriva de la luz», una «luz capaz de poner en fuga a los demonios que, por tenebrosos, aman las tinieblas $y$ aborrecen la luz». ${ }^{88}$

La presencia de Dios no es visible ni puede comprenderse con evidencias, obvias para todos. La luz de Dios es una luz metafísica y se capta con el oculus mentis. ${ }^{89}$ El significado de las posibles evidencias (signos o experiencias de la presencia de Dios) está codificado. Para entenderlo es necesario acudir a su palabra, recibida por los profetas y recogida en las Escrituras. Y asumir que esta luz puede llegar velada, "disminuida", como verbo de oro recubierto de plata. ${ }^{90}$

Servet asocia la naturaleza de Dios con la luz, un elemento que a diferencia del resto de la materia no puede ni dividirse ni corromperse:

Así como la luz del sol se distribuye cada vez con más abundancia conservando continuidad hasta su origen, así la luz de Dios se distribuye cada vez más débilmente; pero aquella se destruye, y esta no. Todo cuanto hay en el mundo es materia crasa, divisible y penetrable, en comparación con la luz de la palabra y del espíritu. Esa luz[...]penetra y colma toda la sustancia misma del ángel y del alma igual que la luz solar penetra y llena el aire. Incluso penetra y sostiene todas las formas del mundo, ya que es forma de las formas[...] Dios no es divisible, ni es divisible la sustancia del verbo, pues todo lo divisible es corruptible. ${ }^{91}$

Con esta descripción se separa de la comprensión de Dios como una criatura a la que se podrían reconocer partes. Como veíamos más arriba, Servet es severo en su crítica hacia los que tratan a Dios como si fuera una criatura que pudiera dividirse o representarse en el espacio:

Ininteligiblemente sueñan con un cerbero de tres cabezas, un Dios tripartito, como si fuesen tres puntos en uno solo, tres cosas encerradas en una sola. Reducen todas las sustancias celestiales a un punto matemático. Incluso llegan a decir que Dios es como un punto repetido infinidad de veces en el mismo plano o como si en un punto hubiera tres. ${ }^{92}$

En lugar de esta comprensión geométrica, Servet indaga en la naturaleza de Dios con un lenguaje cargado de evocaciones:

La sustancia de los ángeles, como la de las almas, no es como un punto. La sustancia misma del espíritu de Dios, de la que emanaron ángeles y almas, tampoco era como la de un punto, sino como de sustancia de un viento elemental. ${ }^{93}$

\section{EL DEXAMIENTO Y LA ORACIÓN MENTAL}

La luz de Servet se convierte en lumbre espiritual en los alumbrados. Esta lumbre establece un vínculo cálido y reconfortante con Dios en el que no debe mediar la voluntad de los individuos.

88 Ibídem: V, 261 (I, IV).

89 Ibídem: V, 191 (I, III).

90 Ibídem: V, 184 (I, III). Sobre esta metáfora, que también emplea Maimónides, véase Weiss 2008: 3-19.

91 Alcalá 2003-2007: V, 204-205 (I, III). Cursiva en el original.

92 Ibídem: V, 201 (I, III). También ibídem: V, 217 (I, IV).

93 Ibídem: V, 204 (I, III). Cursiva en el original. 
En la comprensión de los alumbrados, la presencia y entidad de Dios se muestra de una forma sencilla, como una presencia interior que colma el corazón de los hombres y a la que estos deben entregarse amorosamente:

[Decía Ruiz de Alcaraz] que nuestro coraçon era mayor que Dios; tiniendo a su coraçon por Dios; e quel sentimiento interior que tenían de Dios o de su natura o lo que en si hallasen, que todo era Dios. ${ }^{94}$

Esta presencia no requiere de ninguna representación o manifestación externa. Es más, rechazan las imágenes que representan a Cristo, a la Virgen y a los santos. De igual manera, rechazan las disciplinas, los ayunos, el darse "golpes de pecho» y la oración vocal, recomendando la oración mental. ${ }^{95}$ Esta ausencia de rituales externos («ese jugar con el cuerpo en la iglesia», según habría dicho Gaspar de Bedoya) ${ }^{96}$ resultaba llamativa para sus vecinos y motivó muchas denuncias:

Que [Ruiz de Alcaraz] no hazia humillaçion ni acatamiento alguno al Santissimo Sacramento del altar, ni se heria en los pechos como los católicos xpianos lo hacen, antes se estaua tieso envarado, y menos hazia umillaçion al nombre de Ihesu, teniéndolo por inperfeçion, y ansi lo enseñando. ${ }^{97}$

La rea [Isabel de la Cruz] mientras oía misa estaba con la cabeza erguida, en español, sesga o yerta, mirando de hito en hito el sacramento de la Eucaristía, sin darse golpes de pecho. ${ }^{98}$

Esta doctrina no valía para cualquiera. Isabel de la Cruz parecía distinguir entre dos grupos, según su nivel de preparación espiritual. A los principiantes les aconsejaba que se diesen a «disciplinas e ayunos e oraciones e a pensar en la pasión de dios y en los beneficios que de el avian rescibido" y les daba para ello «libros en que leyesen e disciplinas con que se diciplinasen» mientras que los que ya estaban más instruidos, como el propio Ruiz de Alcaraz, «les dezia que no se curasen ya de aquellas cosas que eran baxas sino quando sintiesen alguna repunancia sino que procurasen de estar siempre suspensos en el deseo y amor de dios». Consideraba que hacer obras exteriores era algo "rastrero» y "bajo». ${ }^{99}$ La explicación de esta actitud es que consideraban que todos esos rituales, en el fondo, no estaban movidos por el amor a Dios sino por el amor propio. ${ }^{100}$ Además, eran lesivos para la libertad del alma. El alma corría el peligro de quedar "atada» a rituales y a objetos vacíos de espiritualidad. ${ }^{101}$ "[E]l que se quedaba en los medios», habría dicho Isabel de la Cruz, "no alcanzaría el fin». ${ }^{102}$

En esta comprensión interiorizada de lafe, los especialistas han considerado una cercanía entre el dexamiento y el recogimiento practicado por los franciscanos. ${ }^{103}$ Igualmente

\footnotetext{
94 Serrano y Sanz 1903: 22.

95 Véanse especialmente las proposiciones 11, 13-20, 24 y 27 del Edicto de 1525. Márquez 1980: 232-235.

96 Ibídem: 287.

97 Serrano y Sanz 1903: 22.

98 Márquez 1980: 269.

99 Longhurst 1957: 289-290 y 293. Énfasis añadido.

100 Serrano y Sanz 1903: 24.

101 Márquez 1980: 252-253, 269-271.

102 Ibídem: 268

103 Por ejemplo, Hamilton 1992: 12-16, 29-32. De manera didáctica,
} García Gutiérrez hace un repaso de las diversas corrientes con las que se se ha observado que esta reticencia a la exteriorización de la fe puede ser fruto del ambiente converso en el que se gesta el alumbradismo:

Convertidos a la fuerza, tanto judíos como musulmanes, se ven obligados a practicar las ceremonias de una religión en la que no creen y a la que odian[...] Para la porción más escogida de este o estos pueblos subyugados, la ecclesia spiritualis era no sólo la salida lógica; era la única posible. Nos parece que es en este sentido como hay que entender la contribución de los conversos, tanto judíos como islámicos, a la formación del iluminismo en Castilla. ${ }^{104}$

Paradójicamente esa interiorización espiritual no supuso ninguna protección ${ }^{105}$, sino que más bien les delataba, como señalábamos más arriba al mencionar su actitud en la iglesia. ${ }^{106}$

Más interesante aún resulta considerar que en el planteamiento de los alumbrados se asume y se acepta la impotencia de la voluntad para lograr la perfección moral. Ante el dilema que había puesto en palabras Pablo de Tarso - «no hago el bien que quiero, sino que obro el mal que no quiero» (Rom 7, 19)-, los alumbrados recomiendan confiarse en Dios y vivir las tentaciones sin oponerles resistencia. ${ }^{107}$ Según un testimonio recogido en el Proceso de Isabel de la Cruz, para ella "toda la vida del alma» consistiría en «que Dios hiciese su voluntad en nosotros, sin contradicción nuestra». ${ }^{108}$ En este entendimiento no parece aceptable considerar que el individuo sea capaz por sí mismo de edificar su alma. A Ruiz de Alcaraz le acusaban de decir que:

[C]uando le manifestaron el templo a Cristo y Cristo dijo «no ha de quedar piedra sobre piedra» [se entiende] que todo edificio espiritual hecho por el hombre es nada y será destruido. ${ }^{109}$

El título de la principal obra de Servet, Restitución del Cristianismo, también parece evadirse del propósito edificador de la Institución de la Religión Cristiana de su contemporáneo Calvino. ${ }^{110}$

ha tratado de vincular a los alumbrados. García Gutiérrez 1999: 76-159. También hay una revisión de conjunto, aunque menos ecuánime, en Santonja 2001. Augusta Foley apuntaba varias posibles sendas para indagar en los orígenes del alumbradismo, entre ellas la de los espíritus libres, un camino que ha seguido Tausiet 2013. Foley 1986: 532.

104 Márquez 1980: 89.

105 Isabel de la Cruz señaló que no había confesado nada de sus convicciones porque "no la entenderían» pues eran "cosas espirituales de alta contemplación» y porque "estas cosas eran espirituales, y no exteriores, y creía que no estaba obligada a decir esto». Márquez 1980: 275.

106 Precisamente María de Cazalla en su defensa niega que no mirara a la hostia consagrada intencionadamente, pues actuar así sería exponerse públicamente. Ortega 1978: 203.

107 Márquez 1980: 237. María de Cazalla refiere este pasaje de Pablo cuando formula su defensa ante la acusación de un testigo de no aceptar el libre albedrío. Señala que en todo caso ella habría referido ese pensamiento de Pablo, también presente en San Agustín. Véase Ortega 1978: 222-223.

108 Márquez 1980: 264.

109 Ibídem: 250

110 Sintonizamos en este punto con Alcalá cuando escribe que Servet «jamás asumiría, como Calvino, la soberbia tarea de instituir el cristianismo: se conforma con restituirlo, se siente en sintonía con las gentes judías que, sin previas metafísicas, seguían a Jesús como él les dirá luego a Calvino en las Cartas y a Melanchton en la Apología». Alcalá 2003-2007: I, XLII-XLIII. 


\section{CONCLUSIÓN}

La experiencia de los alumbrados en sus conventículos y las indagaciones teológicas de Miguel Servet que han quedado registradas en sus escritos nos ofrecen dos muestras de una espiritualidad cristiana singular que brotaron en el siglo dieciséis en la península ibérica. Cada una a su manera, muestran el deseo de vivir de un modo genuino la fe cristiana. Como tal, expresan la búsqueda y la experiencia de una libertad interior de raíces muy profundas; una libertad espiritual que sin embargo careció de instrumentos externos para protegerse ante la inspección y persecución de las instituciones dedicadas al mantenimiento de la ortodoxia religiosa. Es por ello que junto a su intensa libertad observamos su impotencia política. Servet no fue un líder religioso como sí lo fueron muchos de los reformadores con los que se mantuvo en comunicación. Desarrolló su obra como una actividad de búsqueda individual.

Los alumbrados, por su parte, sí se constituyeron como un grupo más o menos articulado. Sin embargo, compatibilizaron su manera de entender la fe y de orientar su vida espiritual con la pertenencia a la Iglesia oficial. Su preocupación radicaba en la entraña no visible de la vida cristiana, no en su organización institucional; una entraña que, como sus testimonios denuncian veladamente, quedaba enmascarada y deformada bajo una parafernalia de gestos externos carentes de verdadera piedad. ${ }^{111}$

En su manera de guiar su inteligencia y su corazón en la búsqueda de Dios y en su modo de entender el mejor modo de gobernar su conducta descubrimos además una sensibilidad particular que no sucumbe ante el poderío de la voluntad y el control que se impondrá en la mentalidad europea. ${ }^{112}$ Aquí la noción de impotencia que atribuimos a estas experiencias adquiere una dimensión más profunda y trascendental. En la manera de indagar en las cuestiones de fe en Servet observamos su delicada comprensión de la interpretación de las Escrituras y su capacidad de dar entrada a la letargia; es decir, a esa capacidad de la inteligencia que opera más allá del control consciente y la dirección de la voluntad. En el caso de los alumbrados, es valiosa su noción del dexamiento en Dios, que revela una aceptación de la impotencia.

En ambos planteamientos la voluntad no se vislumbra como el dispositivo eficaz sobre el que debe pivotar el autogobierno espiritual; el yo volente no se corona como el instrumento básico para la liberación del alma. Su punto de partida más bien es la aceptación de la fragilidad de la voluntad y las limitaciones del intelecto humano. Valorar estos rasgos, que hemos tratado de exponer en este trabajo, puede ser relevante para considerar las teorías de gobierno dominantes en sus contornos, en las que empieza a brillar con fuerza la noción de soberanía.

111 Ante las prácticas excesivas de algunas mujeres, que acudían varias veces a misa al día, exclama María de Cazalla: «'¡Oh señor! ¡Qué çeguedad está enl mundo que te busquen solament[e] en los templos fechos de mano y en sy, que son templos bivos, no te busquen ni te hallen!'». Ortega 1978: 219.

112 Es muy relevante el interés que existe en el siglo diecisiete por guiar y establecer reglas que permitan gobernar el intelecto, al tiempo que se están elaborando teorías para fundamentar el poder del Estado basadas en la aceptación voluntaria de un pacto. En este sentido puede considerarse el Discurso del Método (1637) de René Descartes (15961650). La noción de método y la ventaja que supone ordenar el pensamiento y los conocimientos, sin embargo, comienza a adquirir relevancia en el siglo dieciséis de la mano, entre otros, del humanista francés Pierre de la Ramée (1515-1572). Véase Adrián Lara 2015.

\section{BibliografíA}

Adrián Lara, L. 2015. Dialéctica y calvinismo: Una reflexión desde la teoría política. Madrid: Centro de Estudios Políticos y Constitucionales.

Alcalá, Á. (ed.). 2003-2007. Miguel Servet. Obras completas. 6 vols. Zaragoza: Prensas Universitarias.

Aristóteles. 1982. Metafísica. [trad. de V. García Yebra]. Madrid: Gredos.

Biblia de Jerusalén. 2009. Nueva edición, totalmente revisada. Bilbao: Desclée de Brouwer.

Canabal Rodríguez, L. 2001. «Heterodoxia en el reinado del Emperador: Toledo, los alumbrados e Isabel de la Cruz», en J. Martínez Millán (coord.), Carlos $V$ y la quiebra del humanismo político en Europa (1530-1558), Congreso internacional, Madrid 3-6 de julio de 2000, vol. 4: 309-332. Madrid: Sociedad Estatal para la conmemoración de los Centenarios de Felipe II y Carlos V.

Calvin, J. 1957. Institution de la Religion Chrétienne. [ed. de J.-D. Benoît, edition critique avec introduction, notes et variantes]. 5 vols. Paris: Vrin.

Foley, A. E. 1986. "El alumbradismo y sus posibles orígenes», en A. D. Kossoff, G. Ribbans, J. Amor y Vázquez (eds.), Actas del VIII Congreso de la Asociación Internacional de Hispanistas: 527-532. Madrid: Istmo.

García Gutiérrez, J. Mạ 1999. La herejía de los alumbrados. Historia y filosofía: de Castilla a Extremadura. Madrid: Mileto ediciones.

Hamilton, A. 1992. Heresy and Mysticism in Sixteenth-Century Spain: The Alumbrados. Cambridge: James Clarke \& Co.

Huerga. A. 1978. Historia de los alumbrados (1570-1630). 5 vols. Madrid: FUE.

Longhurst, H. E. 1957. "La beata Isabel de la Cruz ante la Inquisición (1525-1529)». Cuadernos de Historia de España 15-16: 279-303.

Lutero, M. 1986. Escritos políticos. [Estudio preliminar y traducción de Joaquín Abellán]. Madrid: Tecnos.

Márquez, A. 1980. Los alumbrados. Orígenes y filosofía (1525-1559). Madrid: Taurus.

Márquez, A. 1989. "Juan de Quintana, Servet y los alumbrados». Argensola: Revista de Ciencias Sociales del Instituto de Estudios Altoaragoneses 102: 181-190.

Molinos, M. 1974. Guía espiritual. [ed. de J. A. Valente]. Barcelona: Barral.

Newman, L. I. 1966. "Michael Servetus, the antitrinitarian Judaizer», en Jewish Influence upon Christian Reform Movements (1925): 511-609. New York: Amm Press.

Ortega, M. 1978. Proceso inquisitorial contra María de Cazalla (1534). Madrid: Fundación Universitaria Española.

Roiz, J. 2003. La recuperación del buen juicio. Teoría política en el siglo veinte. Madrid: Editorial Foro Interno.

Roiz, J. 2008. Sociedad vigilante y mundo judio en la concepción del Estado. Madrid: Editorial Complutense.

Santonja, P. 2001. La herejía de los alumbrados y la espiritualidad en la España del siglo XVI. Valencia: Biblioteca Valenciana.

Serrano y Sanz, M. 1903. «Pedro Ruiz Alcaraz, iluminado alcarreño del siglo XVI». Revista de Archivos, Bibliotecas y Museos VIII (2): 8-31.

Strauss, L. 1996. "Atenas y Jerusalén: Algunas reflexiones preliminares», en Persecución y arte de escribir y otros ensayos de filosofía política: 104. Valencia: Edicions Alfons el Magnànim.

Simpson, J. 2007. Burning to Read. English Fundamentalism and its Reformation Opponents. Cambridge, London: Harvard University Press.

Tausiet, M. 2010. «Mago contra falsario: un duelo de insultos entre Calvino y Servet». Hispania Sacra 62 (125): 181-211.

Tausiet, M. 2013. "Espíritus libres. El alumbradismo y Miguel Servet». Hispania Sacra 65 (131): 73-102.

Walzer, M. 2008. La revolución de los santos. Estudio sobre los orígenes de la política radical [1965.Traducción de S. Villegas]. Buenos Aires: Katz.

Weiss, R. 2008. «Four Parables about Peshat as Parable». CCAR Journal: A Reform Jewish Quarterly 4: 3-19. 